\title{
Usage of a Translated Version of Terminologia Anatomica in Brazil: An Examination of the Neurosurgical Literature
}

\section{Aderência à versão traduzida da terminologia anatômica no Brasil: Análise da literatura neurocirúrgica}

\author{
Krysna Pires Lessa ${ }^{1}$ Ítalo Gonçalo Matias Vilasbôas ${ }^{2}$ \\ Igor Lima Maldonado $3,4,5,6 \odot$ \\ ${ }^{1}$ Department of Life Sciences, Universidade do Estado da Bahia, \\ Salvador, Brazil \\ 2 Faculty of Medicine, Universidade Federal da Bahia, Salvador, Brazil \\ ${ }^{3}$ Department of Biomorphology, Instituto de Ciências da Saúde, \\ Universidade Federal da Bahia, Salvador, Brazil \\ 4 Postgraduate Program in Medicine and Health, Universidade Federal \\ da Bahia, Salvador, Brazil \\ ${ }^{5}$ UMR Inserm U1253, iBrain, Université de Tours, Tours, France \\ ${ }^{6}$ Le Studium Loire Valley Institute for Advanced Studies, Orleans, \\ France
}

Arq Bras Neurocir 2019;38:106-111.
Marcos de Amorim Aquino ${ }^{3}$

Address for correspondence Igor Lima Maldonado, Departamento de Biomorfologia, Instituto de Ciências da Saúde, Universidade Federal da Bahia, Avenida Reitor Miguel Calmom s/n. Vale do Canela Salvador, BA, 40110-100, Brazil (e-mail: igorlimamaldonado@gmail.com).

\begin{abstract}
Keywords

- anatomical terminology

- anatomical nomenclature

- terminology

- neuroanatomy

- anatomy

Introduction The linguistic factor may have delayed the universal adoption of the International Anatomical Terminology (IAT), which was widespread in Latin and in English only. Independent translations are possible, but they are not devoid of methodological difficulties.

Objective To estimate the usage of the translated version of the Terminologia Anatomica in neurosurgical articles in Brazil.

Method Consecutive national publications were checked for the correspondence of their anatomical terms to the following categories: IAT - Brazilian version; IAT in Latin; Nomina Anatomica - previous versions; incomplete terms; derivative terms; eponyms; neologisms; and others (misspellings and prosaic terms). The years 2014 and 2015 were chosen for analysis so that included articles were published at least 16 years after the publication of the original IAT (1998) and at least 13 years since the publication of the Brazilian version (2001).

Results Out of a total of 183 articles analyzed, 1,132 anatomical terms were identified, referring to 334 different anatomical structures. Most of the structures were described using terms from the Brazilian version of the IAT $(n=834 ; 73.7 \%)$. Those that did not belong to or did not derive from any version of the IAT totaled 281 (24.8\%). The remaining 17 terms (1.5\%) corresponded to words derived or provided for
\end{abstract}

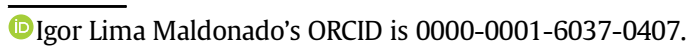

received

October 15, 2018

accepted

February 19, 2019
DOI https://doi.org/

10.1055/s-0039-1685154. ISSN 0103-5355.
Copyright (e) 2019 by Thieme Revinter

Publicações Ltda, Rio de Janeiro, Brazil
License terms

(c) $(1) \$$ 


\section{Resumo \\ Palavras-chave \\ - terminologia anatômica \\ - nomenclatura anatômica \\ - terminologia \\ - neuroanatomia \\ Introdução $O$ fator linguístico pode ter retardado a adoção universal da terminologia anatômica internacional (TAI), que foi originalmente difundida apenas em latim e em inglês. Traduções independentes são possíveis, mas não desprovidas de dificuldades metodológicas. \\ Objetivo Estimar o uso da versão traduzida da terminologia anatômica em artigos neurocirúrgicos no Brasil. \\ Método Publicações nacionais consecutivas foram verificadas quanto à correspondên- cia de seus termos anatômicos com as seguintes categorias: TAI - versão brasileira; TAI em latim; Nomina Anatomica - versões anteriores; termos incompletos; termos derivados; epônimos; neologismos e outros (erros ortográficos e termos prosaicos). Os anos de 2014 e 2015 foram escolhidos para análise de forma que os artigos incluídos foram publicados no mínimo 16 anos após a publicação do IAT original (1998) e pelo menos 13 anos desde a publicação da versão brasileira (2001). \\ Resultados Dos 183 artigos analisados, 1.132 termos anatômicos foram identificados, referentes a 334 diferentes estruturas anatômicas. A maioria das estruturas foi descrita usando termos da versão brasileira da $\operatorname{TAl}(n=834 ; 73,7 \%)$. Aqueles que não pertenciam ou derivavam de qualquer versão da TAl totalizaram 281 (24,8\%). Os 17 termos restantes (1,5\%) correspondiam a palavras derivadas ou previstas na TAl em latim. Nenhuma associação foi identificada entre o número de autores e qualquer categoria de nomenclatura. \\ Conclusão Embora a maioria das estruturas anatômicas citadas em português tenha sido descrita de acordo com a versão brasileira da TAI, o grau de adesão foi considerado moderado, pois cerca de um quarto dos termos escapou dessa terminologia.}

in the Latin IAT. No association was identified between the number of authors and any category of nomenclature.

Conclusion Although most anatomical structures cited in Portuguese were described in accordance with the Brazilian version of the IAT, the degree of adherence was considered moderate given that about one-quarter of the terms escaped this terminology.

\section{Introduction}

Anatomical terminology is one of the bases for the proper description of the human body. It is used not only in educational and forensic activities but also in diagnostic and therapeutic procedures. ${ }^{1}$ Anatomical terminology was created to standardize language and prevent the same structure from being cited in various ways, which could be a source of controversy or confusion. ${ }^{2,3}$

The first nomenclature was published in 1895 as Basiliensia Nomina Anatomica. Seven revisions followed: Jenaiensia Nomina Anatomica in 1935, Parisiensia Nomina Anatomica in 1955, and five other editions of Nomina Anatomica between 1960 and $1989 .{ }^{4}$ They were replaced by the Terminologia Anatomica, which was prepared by the Federation Committee on Anatomical Terminology, and was approved and made official by the International Federation of Associations of Anatomists in 1998 in Latin and in English. 5,6 This last version was then translated into Portuguese and published by the Anatomical Terminology Commission of the Brazilian Society of Anatomy in 2001. 7,8

The year of 2018 marks 20 years since the first publication of Terminologia Anatomica and is an opportune time to evaluate how its usage has materialized among researchers and health professionals. Nomenclature modifications impose relatively abrupt changes, but the adhesion of the scientific community is progressive and influenced by the peculiarities of each area of activity. It is expected that this phenomenon does not happen in the exact same way and with the same rhythm among anatomists and practitioners. In contrast, the importance of developing a universal language is well recognized among different subgroups. Therefore, the objective of the present study was to estimate the adherence to the translated International Anatomical Terminology (IAT) by authors of neurosurgical scientific articles in Brazil. A quantitative analysis was performed to identify the terminology standards in the publications that were used to describe the central nervous system, its surrounding structures, and the cranial nerves.

\section{Method}

This was a descriptive study in which the terms used to designate anatomical structures in each publication were checked regarding the Brazilian version of the IAT. If not adhering to the IAT, the terms were classified in alternative 
nomenclature categories (described below) for accounting and statistical evaluation.

\section{Search and Selection Strategy}

The journals consulted for analysis were national neurosurgical periodicals publishing articles in Portuguese and indexed in at least one of the following databases: MEDLINE, LILACS, SciELO, DOAJ, or LATINDEX. The years 2014 and 2015 were chosen for analysis so that the articles included were published at least 16 years after the publication of the English and Latin versions of the IAT (1998) and at least 13 years since the publication of the Brazilian version (2001).

All of the scientific articles published during the study period were listed exhaustively for each periodical following direct consultation of the electronic portal of each volume. After the identification, the full text of each document was accessed to verify the following inclusion criteria: published between January 1, 2014, and December 31, 2015, and written in whole or in part in Portuguese. We have excluded publications that did not refer to anatomical structures. In bilingual publications, only the sections in Portuguese (title and abstract) were evaluated.

\section{Data Collection}

The included articles were submitted to a detailed full-text analysis by two independent researchers. Each document received a registration number, which was associated with descriptive data, including year of publication, languages, and number of authors. During the analysis of each document, anatomical structures belonging to the central nervous system (CNS) (including vascularization), its surrounding tissues, or the cranial nerves were identified and listed in a computerized database using Excel software (Microsoft Corp., Redmond, WA, USA). The anatomical terms used by the authors to refer to each structure were classified into one of the following categories: IAT - Brazilian version; IAT - Latin version; Anatomical Nomenclature - previous versions; incomplete terms (but in accordance with the IAT); derivative terms; eponyms; and neologisms.

Names that are commonly used but are not based on the anatomical conventions were categorized as prosaic terms. These terms, as well as those containing misspellings or not provided for in any of the previous classifications, were allocated to the others category. Words denoting pathological formations were not considered anatomical terms and therefore were not accounted for.

Two independent evaluators performed the consecutive categorization. Cases of disagreement were resolved through consensus. In situations in which consensus was not possible, the final category was decided by a vote through the addition of a third evaluator.

\section{Statistical Analysis}

Frequencies and percentages were calculated for categorical variables. Mean and median values were obtained as central tendency measures for continuous and discrete quantitative variables, followed by standard deviations (SDs), confidence intervals (CIs), minimum values, and maximum or inter- quartile intervals when pertinent. It was defined that a structure mentioned several times using the same term in the same publication would be accounted for as a single entry. Thus, each entry represented the choice of the author per anatomical structure and per scientific article.

In addition to the descriptive analysis, terms were grouped according to the year of their publication and to the number of authors of the article $(\leq 5$ authors or $>5$ authors). For the two-tailed comparison of the frequency of a terminology category between two groups, the G-test or the $x 2$ (chi-squared) test for two independent variables was applied. Statistical analysis was performed using BioEstat version 5.0 software (Brazilian Institute of Science and Technology \& University of Illinois, Belém, PA, Brazil), adopting a 95\% CI and a statistical significance level of $p<0.05$.

\section{Results}

\section{Number and Characteristics of the Publications}

We have identified 217 articles from 2 scientific journals. Four were not included because they were entirely written in another language (English or Spanish). Thirty were analyzed but were excluded because they did not refer to any structure in the CNS, its surrounding tissues, or the cranial nerves.

In the 183 articles included in the study, 1,132 anatomical terms were identified, referring to 335 different structures ( - Fig. 1). Most of the articles had $\leq 5$ authors $(n=141 ; 77 \%$ ), ranging from 1 to 13 with mean and median equal to 5.0 .

\section{Terminology Standards}

- Table 1 summarizes the classification of terms referring to anatomical structures. Most structures were described with terms present in the Brazilian version of the IAT ( $n=834$; $73.7 \%$ ). Terms not belonging to or not deriving from the IAT totaled 281 (24.8\%). The use of the English version of the IAT was not observed in the sample, which, due to the inclusion criteria, was made of articles written in whole or in part in the Portuguese language. No statistical association was identified between the number of authors and any category of nomenclature. The most commonly used prosaic term was scalp (couro cabeludo, 8.5\%).

\section{Discussion}

The establishment of terminologies is inseparable from specialized knowledge. However, historical phenomena, local traditions, innovations, and language barriers influence the use of international conventions. In the present study, the adoption of the current Brazilian version of the IAT was estimated quantitatively in neurosurgical publications. A moderate degree of adhesion was observed, with about three-quarters of the anatomical terms present or derived from the IAT.

The relative adherence observed in the present study is not a universal or timeless phenomenon. In a Czech publication, Kachlik et al call attention to the fact that obsolete terms are used in clinical practice - some of them almost exclusively by clinicians - even though corresponding terms are 


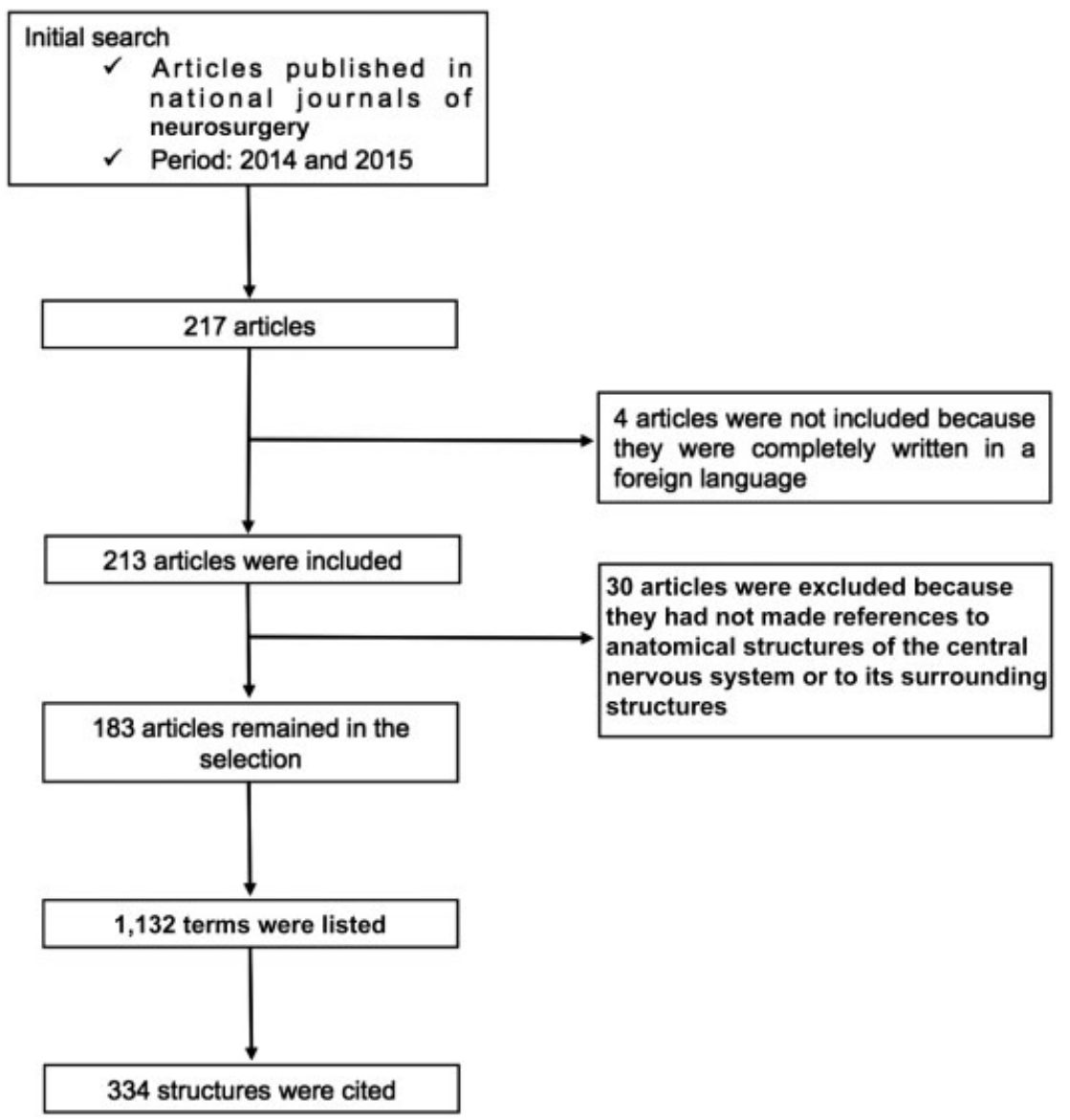

Fig. 1 Flowchart, selection of scientific articles

already available in the anatomical terminology. ${ }^{9}$ In spite of the peculiarities inherent to each country, the temporal nature of the transformations imposed by nomenclature revisions is tangible. Reforms tend to be adopted first by morphologists, teaching professionals, and students. ${ }^{9,10}$ Only later do they spread widely among nonmorphologists and individuals with more time since training.

For monitoring, it is important to assess the evolution of adherence among health professionals. Health care activities are associated with habits of spoken and written languages that are specific to each area. Although the clinical terminology is very similar to the IAT, it is not agreed by a standard vocabulary, as is the case of anatomy. ${ }^{11}$ One such example is the use of eponyms. Although abolished in the current IAT, they remain ever present in surgical and diagnostic procedures, which reinforces their daily use.

In a survey of the frequency of their use in electronic publications of the Journal of Neurology of Spain, Abdala listed 193 eponyms in 46 documents. The most frequent were terms related to the vascular or cerebrospinal fluid system. Expressions such as "Galeno vein" (14\%), "Willis polygon" (11.9\%), and "cerebral or Sylvian aqueduct" (11.4\%) were found mainly in clinical or radiological reports such as those related to computed tomography (CT), magnetic resonance imaging (MRI) or ultrasound (US). ${ }^{12}$

Certain factors impact negatively or delay the adherence to the IAT, such as the difficulty in obtaining copies, the absence of an accessible electronic database, and the tendency in certain languages or countries to avoid Latin terms. ${ }^{2,3,10,11,13,14}$ Some authors consider the linguistic factor to have considerably delayed the universal adoption of the IAT. ${ }^{14-16}$ Independent translations are not devoid of problems and of methodological difficulties. Although anatomical nomenclature was classically based in Latin, the previous Anatomical Nomina has been translated into several languages. This was not the case for the current terminology, which was widespread in Latin and in English.

Ten years after the publication of the IAT in Latin and in English, Martin et al surveyed 121 members of the American Association of Anatomists related to teaching activities. ${ }^{14}$ The participants were consulted by electronic messages that contained 25 sets of expressions considered synonymous or equivalent. Among them were IAT terms, but also older and more clearly established ones. Other questions established the profile of the participants and their familiarity with the IAT. The results showed a preference for terms not belonging to the IAT in 13 of the 25 questions. The preference for the official terms was extremely variable depending on the issue: from 0.8 to $98.4 \%$. Interestingly, more than $76 \%$ of the participants did not consider themselves familiar enough with the current terminology, and there was a slight correlation between familiarity and the belief that multiple synonyms are a source of concern in the exercise of teaching activities. The authors 
Table 1 Frequency of nomenclature standards used in 1,132 anatomical terms identified in 217 scientific articles written totally or partially in Portuguese in Brazilian neurosurgical papers

\begin{tabular}{|l|l|l|l|}
\hline Category & $\mathbf{n}(\%)$ & Example & Brazilian IAT \\
\hline IAT - Brazilian version & $834(73.7)$ & artéria cerebral anterior & $\begin{array}{l}\text { artéria cerebral anterior } \\
\text { (anterior cerebral artery) }\end{array}$ \\
\hline IAT - in Latin & $3(0.3)$ & septum pellucidum & septo pelúcido \\
\hline Derivative terms & $14(1.2)$ & base craniana & $\begin{array}{l}\text { base do crânio } \\
\text { (skull base) }\end{array}$ \\
\hline Incomplete Terms & $99(8.7)$ & pineal & $\begin{array}{l}\text { glândula pineal } \\
\text { (pineal gland) }\end{array}$ \\
\hline Anatomical Nomenclature - previous versions & $91(8.0)$ & tronco cerebral & $\begin{array}{l}\text { tronco encefálico } \\
\text { (brain stem) }\end{array}$ \\
\hline Eponyms & $20(1.8)$ & polígono de Willis & $\begin{array}{l}\text { círculo arterial do cérebro } \\
\text { (cerebral arterial circle) }\end{array}$ \\
\hline Neologisms & $12(1.1)$ & coluna espinhal & $\begin{array}{l}\text { coluna vertebral } \\
\text { (spine) }\end{array}$ \\
\hline Other & $59(5.2)$ & & $\begin{array}{l}\text { cauda equina } \\
\text { (cauda equina) }\end{array}$ \\
\hline Misspelling & 8 & calda equina & Calvaria \\
(calvaria)
\end{tabular}

Abbreviation: IAT, International Anatomical Terminology

suggest that the length of teaching experience is related to greater resistance to the new terms.

A similar survey among members of the American Association of Clinical Anatomists was conducted in 2014, more than 15 years after the publication of the IAT. ${ }^{11}$ Official terms were preferred in only 13 out of 25 of the issues. Almost 25\% of the participants stated that they were unfamiliar with the terminology, and 75\% expressed concern about problems related to synonymy.

Some specific cases in Brazilian neurosurgical publications analyzed in the study are worthy of attention. One is the use of prosaic terms that do not belong to the IAT. The term couro cabeludo (Brazilian expression for scalp) is widely used in everyday language as well in scientific documents and human morphology books. Such situations lead to discussions on whether the IAT should include routinely used terms. Some authors consider neuroanatomy to be particularly responsible for advances in the description of "new structures" and, consequently, new terms that could be added to the official terminology. ${ }^{9}$

A total absence of prosaic terms describing anatomical structures is probably difficult or even impossible to achieve, given specialty traditions, so that avoiding them completely would seem awkward. This is also the case of incomplete terms, as the omission of long anatomical terms is often used as a strategy to ensure the fluidity and readability of the text.

The 2008 IAT and the Histological Terminology sections dedicated to the central and peripheral nervous systems were recently extensively revised by the Federative International Program for Anatomical Terminology Working Group Neuroanatomy, after which members of the International
Federation of Associations of Anatomists were consulted. These 2 sections were subsequently combined in 2017 in a document entitled Neuroanatomical Terminology. ${ }^{17-19}$ Among the main innovations related to the CNS are the implementation of terms for various types of neurons, a better subdivision of infratentorial and supratentorial subarachnoid cisterns, a new version of the vascularization section, a more logical presentation of the subdivision between white and gray matter, a subdivision of the forebrain based on embryology and genoarchitecture, the use of new subdivisions of the thalamic nuclei, an update of the subdivisions and cellular types of the cerebral cortex, and an update on long association pathways. Also, the amygdaloid nucleus, the basal forebrain, and the basal nuclei are now listed under the heading subpallium.

The present study has limitations. Although an exhaustive evaluation was performed, a coverage period of 2 years does not enable extrapolation of results to the entire volume of national publications and all Brazilian neurosurgeons. Furthermore, neurosurgical articles published in nonspecialized journals were not included in the present analysis.

A single evaluation may omit the temporal and evolutionary character of adherence to the AIT. As the academic community appropriates the new norms and authorships are renewed, figures may change. Pertinent future research should involve longitudinal monitoring and repeated evaluations of national publications. Moreover, there is an increasing tendency to use English in national journals. This phenomenon is partly explained by the efforts of authors and editors to increase the circulation of their documents and to fulfill criteria for indexing in international databases. Thus, it seems 
that it will be important to study the adhesion of Brazilian authors to the English version of the IAT in the future.

\section{Conclusion}

According to the results of the present study, most anatomical structures cited in Portuguese in Brazilian neurosurgical journals were described according to the current Brazilian version of the Terminologia Anatomica. The degree of adherence was, however, considered to be moderate, given that approximately one-quarter of the anatomical terms used were not covered by this terminology.

\section{Conflicts of Interests}

The authors have no conflicts of interests to declare.

\section{References}

1 Kachlik D, Baca V, Bozdechova I, Cech P, Musil V. Anatomical terminology and nomenclature: past, present and highlights. Surg Radiol Anat 2008;30(06):459-466. Doi: 10.1007/s00276-0080357-y

2 Pawlina W, Drake R. Moving forward with Terminologia Anatomica. Anat Sci Educ 2009;2(03):93. Doi: 10.1002/ase.89

3 Whitmore I. Terminologia anatomica: new terminology for the new anatomist. Anat Rec 1999;257(02):50-53

4 International Anatomical Nomenclature Committee. NominaAnatomica. 6th Ed. London, UK: Churchill Livingstone; 2111989

5 Whitmore I. Terminologia Anatomica includes terms in English for all scientists writing in English. Anat Sci Educ 2009;2(03):141. Doi: $10.1002 /$ ase. 88

6 Federative Committee on Anatomical Terminology. Terminologia Anatomica: International Anatomical Terminology. 1st Ed. Stuttgart, Germany: Thieme; 2921998
7 Di Dio LJA. Lançamento oficial da Terminologia Anatomica em São Paulo: um marco histórico para a medicina Brasileira. Rev Assoc Med Bras (1992) 2000;46(03):191-193

8 Sociedade Brasileira de Anatomia. Terminologia Anatômica. Manole. São Paulo; 2001:422

9 Kachlik D, Bozdechova I, Cech P, Musil V, Baca V. Mistakes in the usage of anatomical terminology in clinical practice. Biomed Pap Med Fac Univ Palacky Olomouc Czech Repub 2009;153(02): 157-161

10 Laitman JT. The Bible the flock will not follow. Anat Sci Educ 2009; 2(03):137-138. Doi: 10.1002/ase.87

11 Martin BD, Thorpe D, DeLuna V, et al. Frequency in Usage of Terminologia Anatomica Terms by Clinical Anatomists. J Biomed Educ 2014;2014:1-9

12 Abdala P. [Neuroanatomical eponyms in Revista de Neurología on-line]. Rev Neurol 2007;45(04):201-204

13 Manzanares-Céspedes MC. On-line Terminologia Anatomica: a proposal. Anat Sci Educ 2010;3(03):154-155. Doi: 10.1002/ase.149

14 Martin BD, Thorpe D, Barnes R, Deleon M, Hill D. Frequency in usage of FCAT-approved anatomical terms by North American anatomists. Anat Sci Educ 2009;2(03):94-106. Doi: 10.1002/ ase.83

15 Fabry P, Baud R, Burgun A, Lovis C. Amplification of Terminologia anatomica by French language terms using Latin terms matching algorithm: a prototype for other language. Int J Med Inform 2006; 75(07):542-552. Doi: 10.1016/j.ijmedinf.2005.08.008

16 Fabry P, Baud R, Lovis C. Towards a multilingual version of terminologia anatomica. Stud Health Technol Inform 2005;116 (116):665-670

17 FIPAT. Terminologia Neuroanatomica. FIPAT. library.dal.ca. Federative International Programme for Anatomical Terminology, February 2017

18 Ten Donkelaar HJ, Broman J, Neumann PE, et al. Towards a Terminologia Neuroanatomica. Clin Anat 2017;30(02):145-155. Doi: 10.1002/ca.22809

19 Ten Donkelaar HJ, Kachlik D, Tubbs RS. An illustrated terminologia neuroanatomica. New York, NY: Springer Berlin Heidelberg; 2018: 710 